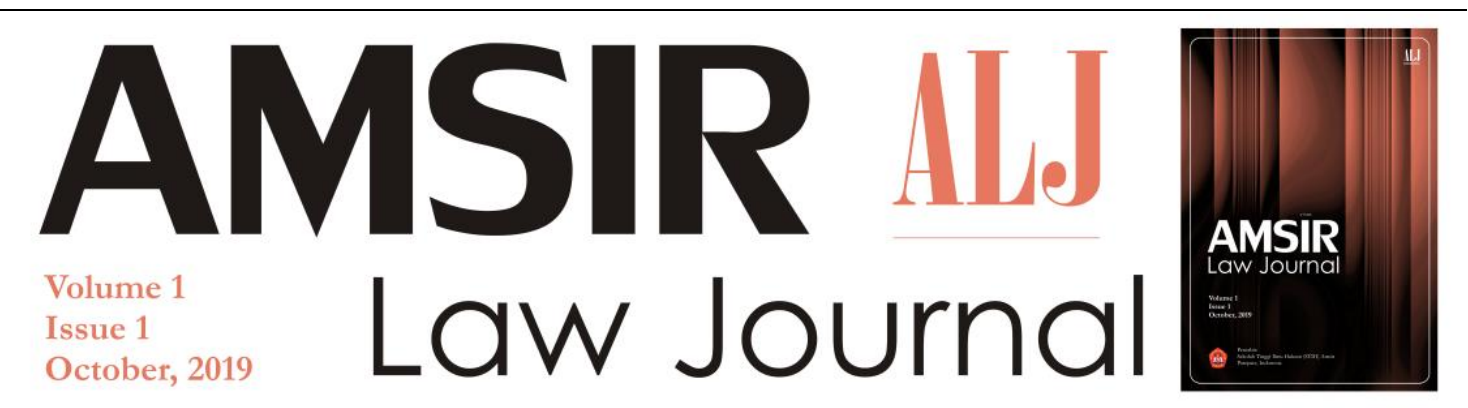

e-issn:

Nationally Accredited Journal, Decree No. ........................

This work is licensed under a Creative Commons Attribution 4.0 International License.

\title{
Dikotomi Politik Hukum Nasional dengan Politik Hukum Adat di Daerah Perbatasan
}

\author{
Julianto Jover Jotam Kalalo, ${ }^{1}$ Irwansyah Irwansyah ${ }^{2}$
}

\section{INFO ARTIKEL}

Kata kunci:

Dichotomy; National Law

Politics; Customary

Politics; Border Areas.

Pengutipan:

Julianto Jover Jotam

Kalalo, Irwansyah

Irwansyah (2019).

Amsir Law Journal, 1(1),

22-35

DOI:

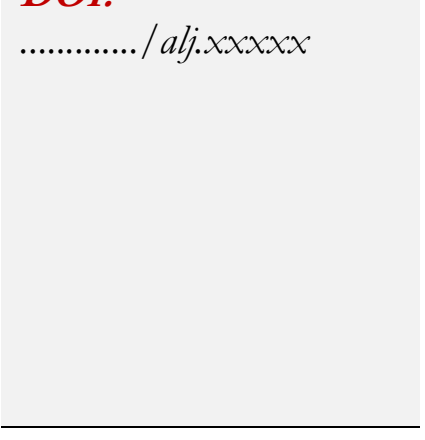

\begin{abstract}
ABSTRAK
The existence of a pluralistic law in the border area causes customary law communities who live and develop in the border area applying variety of laws. The concept of dualism is even deeper in the application of law as a reality that exists in border areas. The position of national law which is side by side with customary law apparently still has a gap which is entered by other countries' laws which are none other than neighboring countries. The existence of this plural law causes the disharmony of the legal regulations applied in the border area. The analysis shows that the dichotomy of regulations often conflicts and differences in the application of the law in each of the legal arrangements. Due to customary politics in the border areas are seeking for the truth in the application of the law. The position of national law does not guarantee the existence of legal arrangements in border areas because customary law in border areas has a strong position. National law is difficult to become a legal basis in border areas. However, the contradictions and differences in these three legal arrangements can actually be synergized, thus, thecontradictions and differences can also form a new law that is dynamic and appropriate, and does not change into a problem in the customary community.
\end{abstract}

Copyright (C) 2019 ALJ. All rights reserved.

1. Pendahuluan

Suatu negara mempunyai perbatasan berupa darat dan laut (laut teritorial). Perbatasan darat meliputi alam (gunung, lembah, sungai, pohon, danau) dan buatan (pagar, kawat berduri, tembok, tugu termasuk juga perjanjian-perjanjian internasional). Batas-batas tersebut difungsikan sebagai "pagar yuridis", "pagar-pagar politis" berlakunya kedaulatan nasional Indonesia dan yurisdiksi nasional Indonesia. Negara Indonesia memiliki perbatasan darat

Fakultas Hukum Universitas Musamus, Indonesia.E-mail: kalalo@unmus.ac.id

Fakultas Hukum Universitas Hasanuddin, Indonesia. E-mail: irwansyab@unhas.ac.id 
dengan beberapa negara, yaitu Negara Malaysia, Negara Timor Leste, dan Negara Papua Nugini. Ketiga daerah perbatasan darat tentunya memiliki corak hidup dan corak hukum yang hampir sama di dalam kehidupan masyarakatnya.

Di daerah perbatasan sudah merupakan hal yang biasa apabila memiliki beberapa pengaturan hukum yang berlaku di dalam persekutuan masyarakat. Dualisme hukum (pluralisme hukum) melahirkan suatu ilmu yang khusus membahas segala masalah yang timbul berkaitan dengan pluralisme hukum yaitu, hukum antar golongan (intergentiel recht). Dalam hukum antar golongan, terdapat asas yang sangat terkenal yaitu "asas penyamarataan" yang artinya, bahwa semua stelsel hukum adalah sama nilainya; adalah sama rata sama harga. ${ }^{3}$

Hukum itu diciptakan bukan semata-mata untuk mengatur, akan tetapi lebih dari itu untuk menciptakan adanya kesejahteraan dan keadilan dalam masyarakat. Maka, hukum itu terus mengikuti perkembangan yang terjadi di masyarakat. Secara empiris hukum dipandang sebagai bagian dari fenomena sosial. Pada awalnya tidak ada keragu-raguan mengenai kemampuan negara untuk secara otonom dan mutlak mengatur serta menata kehidupan masyarakat. Hukum menjadi semacam alat di tangan kekuasaan untuk mewujudkan apa yang dikehendaki. ${ }^{4}$ Perundang-undangan saat ini, dirasakan belum mampu menciptakan rasa keadilan yang dicita-citakan oleh pencari keadilan. ${ }^{5}$ Sehingga keberadaan hukum di luar perundang-undangan yaitu hukum adat menjadi alternatif hukum yang memuat tujuan hukum yaitu rasa keadilan. Akan tetapi, penerapan hukum adat hanya berlaku khusus bagi masyarakat hukum adat yang ada di dalam suatu persekutuan masyarakat hukum adatnya.

Salah satu daerah perbatasan darat di Indonesia yang sangat kental dengan budaya dan adatnya yaitu daerah perbatasan darat Papua dan Papua Nugini (PNG). Berdasarkan perjanjian internasional Indonesia dan Australia mengenai garis-garis batas Indonesia dan PNG yang ditandatangani pada Tanggal 12 Februari 1973 di Jakarta, Pemerintah Indonesia selanjutnya meratifikasi perjanjian tersebut dengan membentuk Undang-undang Nomor 6 Tahun 1973. Selain penetapan perbatasan melalui perjanjian internasional, ternyata di dalam persekutuan masyarakat hukum adat di daerah perbatasan Papua juga memiliki batas-batas adat yang berlaku bagi anggota persekutuan masyarakat hukum adat.

Keberadaan persekutuan masyarakat hukum adat di suatu wilayah ulayat dipisahkan oleh garis perbatasan negara seharusnya membuat keberadaan/kebebasan persekutuan masyarakat hukum adat terbatas oleh batas kedaulatan suatu negara. Akan tetapi, berdasarkan hukum adatnya persekutuan masyarakat hukum adat di daerah perbatasan memiliki kebebasan untuk melakukan perbuatan hukum di daerah wilayah ulayat mereka (tidak terpengaruh dengan adanya perbatasan negara). Masyarakat hukum adat di Indonesia bebas keluar masuk di daerah PNG, bisa tinggal dan bekerja di daerah PNG dan begitu juga sebaliknya warga PNG sering berada di daerah Indonesia untuk tinggal dan bekerja di wilayah yurisdiksi Indonesia. Di daerah perbatasan Merauke ada beberapa kampung yang ditinggali oleh warga PNG, tetapi penerapan hukum yang digunakan beragam. Ada yang menggunakan

Bakri, Muhammad. (2008). Unifikasi dalam Pluralisme Hukum Tanah di Indonesia (Rekonstruksi Konsep Unifikasi dalam UUPA. Jurnal Kertha Patrika. 33 (1), 1-5, hlm. 1.

4 Arinanto, Satya dan Ninuk Triyanti. (2009). Memahami Hukum: dari Konstruksi sampai Implementasi. Jakarta: Rajawali Press, hlm. 8.

5 Likadja, Jeffry Alexander Ch. (2015). Memaknai "Hukum Negara (Law Throught State)" dalam Bingkai "Negara Hukum (Rechtstaat)”. Hasanuddin Law Review. 1 (1), 75-86, hlm. 76. doi:http://dx.doi.org/10.20956/halrev.v1n1.212 
hukum Indonesia, ada menggunakan hukum PNG, dan terakhir penggunaan hukum berdasarkan adat. ${ }^{6}$

Setiap suku bangsa memiliki kemampuan dalam menyelesaikan setiap masalah yang mereka alami. Argumen ini muncul karena manusia sebagai makhluk berpikir selalu berusaha untuk menghadapi apa yang ada dalam kehidupan mereka. Setiap suku bangsa dalam menghadapi masalah selalu menggantungkan diri pada bagaimana leluhur mereka menghadapi hal yang sama. Kondisi ini membuat cara menghadapi masalah merupakan hasil pengetahuan turun-temurun bahkan terkadang dianggap sakral. Pola masyarakat secara turun-temurun dalam menghadapi masalah inilah yang disebut sebagai kebudayaan. Hal ini sesuai dengan konsep kebudayaan yang disampaikan oleh Koentjaraningrat $^{7}$ yang menyatakan bahwa "kebudayaan" adalah keseluruhan sistem gagasan, tindakan dan hasil karya manusia dalam rangka kehidupan masyarakat yang dijadikan milik diri manusia dengan belajar.

Proses penurunan pengetahuan dari leluhur kepada generasi berikutnya merupakan bagian dari proses belajar. Dengan demikian, dapat dikatakan bahwa apapun yang diturunkan oleh leluhur suatu suku bangsa dapat dikatakan sebagai kebudayaan. Hal tersebut berarti bahwa hampir seluruh tindakan manusia adalah "kebudayaan" karena hanya amat sedikit tindakan manusia dalam rangka kehidupan masyarakat yang tak perlu dibiasakan dengan belajar. ${ }^{8}$ Oleh karena itu, bisa dikatakan bahwa pola penyelesaian masalah pada suatu suku bangsa adalah sebuah kebudayaan dari suku bangsa tersebut. Dapat juga disimpulkan bahwa kebudayaan yang dibawa ini merupakan suatu kebiasaan atau dalam bahasa hukumnya disebut sebagai hukum adat.

Referensi dari leluhur merupakan panduan bagi suatu suku bangsa dalam menyelesaikan masalah yang mereka hadapi. Bahkan bisa dikatakan referensi dari leluhur sebagai roh dari kebudayaan suku bangsa/masyarakat hukum adat tersebut. Menurut Rudito dan Famiola, ${ }^{9}$ rangkaian model-model referensi tersebut didasari pada inti dari suatu kebudayaan, inti dari kebudayaan (core of culture) terdiri dari pandangan hidup (world view) dan keyakinan (belief). Keduanya dibungkus oleh ethos (sistem pedoman etika berkenaan dengan baik dan tidak baik). Berdasarkan hal tersebut maka dengan mengetahui pola-pola penyelesaian suku bangsa dalam menghadapi masalah, maka akan didapatkan juga pandangan hidup dan keyakinan yang mereka jalankan sehari-hari.

Cara pandang suku bangsa yang berbeda terhadap masalah yang dihadapi terkadang mengakibatkan munculnya perbedaan. Apa yang menjadi masalah pada suatu suku bangsa, mungkin tidak dianggap penting bagi suku lain. Oleh karena itu, bagi seorang peneliti etnografi menghindari generalisasi terhadap hasil riset yang berbasis suku bangsa sangat dianjurkan. Kondisi yang sama juga muncul dalam budaya kesehatan. Apa yang dianggap penyakit dalam suatu suku, bisa dianggap hal biasa bagi suku liyan. Hal ini merupakan world view yang diyakini berdasarkan pengalaman panjang dalam menghadapi dunia. Konsep world

\footnotetext{
https://elshinta.com/news/86604/2016/11/08/sejumlah-warga-papua-nugini-pindah-ke-indonesia , lihat juga http://beritamerauke.blogspot.co.id/2009/02/57-warga-png-ingin-kembali-ke-merauke.html

Koentjaraningrat. (1990). Pengantar Ilmu Antropologi. Jakarta: PT. Rineka Cipta, hlm. 180.

Ibid.

Rudito, Bambang dan Melia Famiola. (2013). Social Mapping- Metode Pemetaan Sosial: Teknik Memahami Suatu Masyarakat atau Komuniti (edisi revisi). Bandung: Rekayasa Sains, hlm. 4.
} 
view merupakan salah satu unsur terpenting dalam aspek-aspek persepsual komunikasi antar budaya. $^{10}$

Sejarah di tanah Papua, pernah terjadi migrasi masyarakat hukum adat dalam mencari suaka perlindungan ke PNG. Sehingga dalam kehidupan masyarakat terjadi pertemuan budaya hukum: hukum adat persekutuan masyarakat hukum adat; hukum Indonesia; dan hukum PNG di mana tempat mereka bermigrasi. Mengenai bagaimana migrasi membawa perubahan pada masyarakat diungkapkan oleh Koentjaraningrat ${ }^{11}$ sebagai berikut: "Sejak dulu kala dalam sejarah kebudayaan manusia ada gerak migrasi, gerak perpindahan dari sukusuku bangsa di muka bumi. Migrasi tentu menyebabkan pertemuan-pertemuan antara kelompok-kelompok manusia dengan kebudayaan yang berbeda-beda, dan akibatnya ialah bahwa individu-individu dalam kelompok-kelompok itu dihadapkan dengan unsur-unsur kebudayaan asing."

Cara-cara pewarisan pola-pola kebudayaan yang dipunyai oleh masyarakat yang berupa aturan-aturan mengenai status dan peran dalam pranata sosial yang berlaku di masyarakat sering disebut sebagai sosialisasi bila terkait dengan pewarisan status dan peran. Sedangkan secara keseluruhan pola-pola tersebut diwariskan kepada generasi berikutnya atau orang lain yang berasal dari luar masyarakat sering disebut sebagai enkulturasi atau pembudayaan. ${ }^{12}$ Keberadaan hukum yang dibawa oleh masyarakat hukum adat dari PNG merupakan kebiasaan-kebiasaan yang telah tertanam dalam proses pewarisan dari pendahulunya dalam pranata kehidupan hukum bermasyarakat.

Adanya penyimpangan peraturan dalam penerapan hukum di daerah perbatasan disebabkan oleh adanya dualisame bahkan lebih penerapan peraturan yang ada. Ketiga peraturan yang dimaksud adalah peraturan hukum Nasional (Indonesia), peraturan hukum Adat dan peraturan hukum negara tetangga: Papua Nugini. Tigalisme peraturan yang terjadi ini disebabkan karena adanya keseragaman persekutuan masyarakat hukum adat di daerah perbatasan. Masyarakat hukum adat yang berasal dari negara tetangga dan sekarang bermukim di Negara Indonesia membawa sistem hukum PNG. Mereka hidup di Papua dengan menganut sistem hukum nasional, tetapi masih tunduk dan taat dalam suatu persekutuan masyarakat hukum adat Merauke.

Berdasarkan uraian tersebut di atas maka perumusan masalah pada tulisan ini yaitu sebagai berikut: pertama, dikotomi peraturan hukum yang ada di Indonesia khususnya daerah perbatasan dan kedua, kedudukan hukum peraturan perundang-undangan di Indonesia dan politik adat setempat di daerah perbatasan.

Tujuan dari penelitian ini untuk mengkaji dan menjelaskan tentang dikotomi peraturan hukum yang ada di daerah perbatasan. Penelitian ini dimaksudkan untuk menjelaskan secara umum kebijakan-kebijakan pemerintah dalam bentuk undang-undang dan kebijakan lain terhadap keberadaan hukum adat yang ada di daerah setempat dengan indikasi hukum negara tetangga yang ada di daerah perbatasan.

\section{Metode}

Tipe penelitian yang digunakan adalah penelitian hukum normatif dengan menggunakan pendekatan undang-undang (statute approach), pendekatan konsep (conceptual approach),

\footnotetext{
10 Mulyana, Dedi dan Jalaluddin Rakhmat. (2005). Komunikasi Antarbudaya; Panduan Berkomunikasi dengan Orang-orang Berbeda Budaya. Bandung: Remaja Rosdakarya, hlm. 23.

11 Koentjaraningrat, Op.Cit., hlm. 248.

12 Rudito, Bambang dan Melia Famiola. Op.Cit., hlm. 10-11.
} 
pendekatan historis (bistorical approach) dan pendekatan filosofis (philosophy approach). Penelitian dilakukan dengan studi kepustakaan/dokumentasi kemudian dianalisis secara kualitatif berdasarkan bahan hukum primer (peraturan perundang-undangan), bahan hukum sekunder (bahan pustaka dan jurnal ilmiah) maupun bahan hukum tersier (kamus hukum).

\section{Pembahasan}

\subsection{Dikotomi Peraturan Hukum di Daerah Perbatasan}

Negara Indonesia menganut beberapa bentuk sistem hukum yaitu sistem hukum Civil law, Common law, sistem hukum Adat dan sistem hukum Islam. Konsep pluralisme hukum yang berkembang di dalam ranah dikotomi dalam penulisan ini yaitu: antara peraturan perundangundangan Indonesia dan hukum adat setempat, serta hukum dari PNG di daerah perbatasan yang digunakan dalam yurisdiksi kedaulatan NKRI. Pada tahap ini, konsep pluralisme hukum lebih menekankan pada interaksi dan ko-eksistensi berbagai sistem hukum yang memengaruhi bekerjanya norma, proses dan institusi hukum dalam masyarakat.

Secara harfiah dikotomi berasal dari bahasa Inggris yaitu "dichotomy" yang artinya membedakan dan mempertentangkan dua hal yang berbeda. Kata yang dalam bahasa Inggrisnya "dichotomy" tersebut, digunakan sebagai serapan ke dalam bahasa Indonesia menjadi "dikotomi" yang arti harfiahnya dalam Kamus Besar Bahasa Indonesia adalah pembagian atas dua kelompok yang saling bertentangan. ${ }^{13}$ Pius A. Partanto dan M. Dahlan Al-Barry mengartikan bahwa dikotomi sebagai pembagian dalam dua bagian yang saling bertentangan. ${ }^{14}$

Mengacu pada pendapat di atas, penulis mengaitkan dengan pengaturan hukum sehingga menarik kesimpulan bahwa dikotomi hukum adalah pembagian atau pemisahan pengaturan hukum yang saling bertentangan atau pun saling mendukung di dalam penerapan kehidupan bermasyarakat. Dikotomi hukum dalam sistem hukum yang ada di Indonesia adalah pembagian pengaturan hukum Indonesia dalam bentuk peraturan perundangundangan dan hukum adat yang ada dan berkembang di dalam masyarakat. Keadaan pluralisme hukum yang ada di Indonesia membuat keberadaan pengaturan hukum menjadi beraneka ragam. Salah satu contohnya di daerah perbatasan darat Merauke lebih beraneka ragam. Ini dikarenakan dalam kehidupan bermasyarakat terdapat beberapa pengaturan hukum di dalam masyarakat hukum adat.

Proses pembedahan dan pembedaan suatu pengaturan hukum yang ada dalam suatu masyarakat harus melihat dari keberadaan hukum itu berkembang dan hidup pada suatu kehidupan bermasyarakat. Masyarakat yang hidup di daerah perbatasan yang kurang mengetahui akan pengaturan hukum nasional sangat identik dengan hukum adatnya. Keberadaan pengaturan hukum PNG yang dibawa oleh masyarakat hukum adat yang berkewargenagaraan PNG masih melekat dalam kehidupan sehari-harinya, padahal mereka berada di lingkungan hukum Indonesia.

Dikotomi yang terjadi di daerah perbatasan kadang sering bertentangan dan kadang saling mendukung. Ini terlihat bahwa pluralisme hukum yang ada pada masyarakat hukum adat sejalan dan selaras dengan hukum nasional. Keberadaan hukum adat biasa dijadikan sebagai hukum penengah dalam memutuskan suatu permasalahan hukum yang terjadi di daerah perbatasan. Di daerah perbatasan darat Papua khususnya Merauke, keberadaan masyarakat sangat beragam sehingga hukum yang ada dan berkembang juga sangat plural. Pembedahan dan pembedaan penerapan hukum yang ada di masyarakat harus melihat dari

13 Tim Penyusun Kamus Pusat Bahasa. (2001). Kamus Besar Bahasa Indonesia. Jakarta: Balai Pustaka, hlm. 264.

14 Partanto, Pius A. dan M. Dahlan Al-Barry. (1995). Kamus Ilmiah Populer. Surabaya: Arkola, hlm. 110. 
kedudukan dan posisi masyarakat hukum adat di daerah perbatasan tersebut. Sebagian besar masyarakat hukum adat di daerah perbatasan yang berkewarganegaraan Indonesia tunduk terhadap hukum-hukum nasional Indonesia. Akan tetapi, ada juga masyarakat hukum adat PNG yang tinggal di wilayah hukum Indonesia tidak tunduk dan tetap menggunakan hukum PNG yang mereka bawa dari negara tetangga yang diterapkan kepada sesama warga masyarakat hukum adatnya.

Pembedaan dan pertentangan yang sering menimbulkan permasalahan adalah keterlibatan antara masyarakat hukum adat Indonesia dan PNG yang sering menggunakan penerapan hukumnya masing-masing. Dikotomi yang diharuskan dalam penerapan hukum yaitu harus dibedakan terlebih dahulu kedudukan masyarakat hukum adat di daerah perbatasan di mana penerapan hukum yang seharusnya digunakan. Apabila sesama masyarakat hukum adat berkewarganegaraan Indonesia terjadi permasalahan harus diselesaikan dengan hukum Indonesia dan hukum adat yang sesuai dengan ketentuan hukum Indonesia. Apabila sesama masyarakat hukum adat PNG diselesaikan dengan hukum PNG yang berlaku antar warga negara PNG. Namun, jika terjadi permasalahan hukum di wilayah yurisdiksi Negara Indonesia sebaiknya diselesaikan dengan hukum Indonesia atau hukum adat yang sesuai dengan hukum Indonesia. Jika terjadi permasalahan hukum antara kedua masyarakat hukum adat yang berbeda kewarganegaraan sebagai jalan tengah harus menggunakkan penerapan hukum adat yang sesuai dengan hukum Indonesia.

\subsubsection{Politik Peraturan Perundang-undangan di Indonesia}

Peraturan perundang-undangan merupakan bagian atau sub sistem dari sistem hukum. Oleh karena itu, membahas mengenai politik peraturan perundang-undangan pada hakikatnya tidak dapat dipisahkan dari membahas mengenai politik hukum. Istilah politik hukum atau politik perundang-undangan didasarkan pada prinsip bahwa hukum dan/atau peraturan perundang-undangan merupakan bagian dari suatu produk politik karena peraturan perundang-undangan pada dasarnya merupakan rancangan atau hasil desain lembaga politik (politic body). ${ }^{15}$

Politik perundang-undangan merupakan arah kebijakan pemerintah atau negara mengenai arah pengaturan (substansi) hukum yang dituangkan dalam peraturan perundang-undangan (hukum tertulis) untuk mengatur kehidupan berbangsa dan bernegara.

Sebagai bagian dari suatu konsep pembangunan, politik perundang-undangan sudah pasti bertumpu pada suatu landasan (yuridis), yaitu antara lain: (1) Pancasila. Landasan awal dari politik hukum dan peraturan perundang-undangan hal ini dimaksudkan agar kebijakan dan strategi (politik) hukum dan peraturan perundangundangan sejalan sesuai dengan nilai-nilai yang berlaku dalam masyarakat Indonesia dengan tetap membuka diri terhadap berbagai hal-hal yang baik yang merupakan hasil perubahan yang terjadi dalam berbagai bidang kehidupan bermasyarakat, berbangsa, dan bernegara baik di lingkungan pergaulan nasional maupun internasional. (2) Undang-Undang Dasar Negara Republik Indonesia Tahun 1945 (UUD NRI Tahun 1945) merupakan landasan formal dan materiel konstitusional dalam politik hukum dan peraturan perundang-undangan sehingga setiap kebijakan dan strategi di bidang hukum dan peraturan perundang-undangan mendapatkan legitimasi konstitusional sebagai salah satu bentuk penjabaran negara berdasar atas hukum (rechtsstaat) dan asas konstitusionalisme. (3) Peraturan atau Kebijakan implementatif dari politik peraturan

15 Marzuki, H.M. Laica. (2006). Kekuatan Mengikat Putusan Mahkamah Konstitusi terhadap Undang-undang, Jurnal Legislasi. 3 (1), hlm. 2. 
perundang-undangan.Yang dimaksud di sini adalah peraturan atau kebjikan yang memuat aturan-aturan yang berkaitan dengan politik hukum dan peraturan perundangundangan yang bersifat implementatif dari landasan filosofis, konstitusional, operasional, formal, dan prosedural, misalnya antara lain: Undang-Undang Nomor 10 Tahun 2004, Undang-Undang Nomor 23 Tahun 2014 tentang Pemerintahan Daerah, Program Legislasi Nasional (Prolegnas), Rencana Pembangunan Jangka Menengah, dan lain sebagainya.

Politik perundang-undangan merupakan sebagian dari politik hukum. Karena itu sebagai dasar, kebijaksanaan politik hukum berlaku bagi politik perundang-undangan. Politik perundang-undangan berkenaan dengan pembangunan materi hukum meliputi: pertama, pembentukan dan pembaharuan undang-undang; kedua, penginventarisasian dan penyesuaian unsur-unsur tatanan hukum yang berlaku dengan sistem hukum nasional. Meaning of self-regulation is a responsibility to maintain compliance and law enforcement more beld by the public. ${ }^{16}$

Pembentukan dan pembaruan peraturan perundang-undangan diarahkan pada produk-produk hukum baru yang sangat dibutuhkan untuk mendukung tugas umum pemerintahan dan pembangunan nasional. Jadi ada dua bidang utama sasaran pembentukan peraturan perundang-undangan yaitu: (1) Peraturan perundangundangan mengenai tugas umum pemerintahan adalah segala peraturan perundangundangan yang mengatur atau menyangkut penyelenggaraan tugas wewenang pemerintah negara pada bidang ketatanegaraan administrasi negara politik; (2) Peraturan perundang-undangan mengenai pembangunan nasional adalah segala peraturan perundang-undangan yang mengatur dapat memberikan dukungan pada pembangunan nasional.

Mengenai penginventarisasian dan penyesuaian unsur-unsur tatanan hukum yang berlaku dengan sistem hukum nasional adalah berkenaan dengan peraturan perundang-undangan dari masyarakat kolonial yang hingga saat ini masih berlaku. Pengkajian inventarisasi tersebut meliputi: (1) Inventarisasi undang-undang dan berbagai peraturan perundang-undangan termasuk peraturan daerah yang tersusun dan terbentuk untuk kurun waktu tertentu; (2) Melakukan evaluasi internal dan eksternal atas berbagai undang-undang dan berbaga peraturan perundang-undangan lain. Pengkajian internal adalah pengkajian konsistensi ke sistem desain antar berbagai peraturan perundang-undangan. Sedangkan pengkajian relevansi dengan sasaran pembangunan hukum khususnya dan pembangunan pada umumnya.

Pengaturan hukum terhadap wilayah perbatasan diatur didalam UUD NRI 1945 yaitu, pada BAB IXA tentang wilayah Negara Pasal 25A yang berbunyi: Negara Kesatuan Republik Indonesia adalah negara kepulauan yang bercitakan Nusantara dengan wilyah yang batas-batas dan hak-haknya ditetapkan dengan undang-undang. Pasal 25A ini telah dituangkan di dalam Undang-undang Nomor 43 Tahun 2008 tentang Wilayah Negara. Pengaturan nasional terhadap wilayah negara di mana berhubungan dengan wilayah perbatasan ini merupakan kebijakan yang diambil untuk menjaga dan melindungi keutuhan dan kedaulatan Negara Kesatuan Republik Indonesia.

Politik hukum nasional ini belum terimplementasi dengan baik ke dalam ranah masyarakat daerah perbatasan Papua di mana mereka masih memiliki hukum adat yang

16 Irwansyah. (2017). Research-Based Environmental Law: The Debate Between Ecology Versus Development. Sriwijaya Law Review. 1 (1), 44-66, hlm. 49. 
mengikat terhadap persekutuan masyarakat hukum adatnya yaitu masyarakat hukum adat (Warga Negara Indonesia dan Warga Negara PNG). Pengaturan hukum yang berhubungan dengan daerah perbatasan masih sangat kurang dalam upaya penegakan hukum terhadap keberadaan persekutuan masyarakat hukum adat. Belum diaturnya suatu peraturan khusus dalam upaya memperlihatkan posisi dan kedudukan hukum adat di daerah perbatasan persekutuan masyarakat hukum adat yang berbeda kewarganegaraan membuat kekosongan hukum di daerah perbatasan.

Kebijakan lainnya yang diambil oleh pemerintah adalah dengan membuat suatu badan nasional yang mengurus daerah perbatasan yaitu, Badan Nasional Pengelola Perbatasan. Badan Nasional Pengelola Perbatasan adalah Badan Pengelola Batas Wilayah Negara dan Kawasan Perbatasan sebagaimana dimaksud Undang-undang Nomor 43 Tahun 2008 tentang Wilayah Negara. Berdasarkan amanat UU tersebut, pemerintah melalui Peraturan Presiden Nomor 12 Tahun 2010 membentuk Badan Nasional Pengelola perbatasan (BNPP). Dalam konteks pengelolaan batas wilayah negara dan kawasan perbatasan, BNPP mengedepankan sinergi kebijakan dan program, sehingga kelemahan dan keterbatasan yang ada selama ini, yakni penanganan perbatasan negara secara ad hoc dan parsial serta egosektoral, yang telah mengakibatkan overlapping dan redundance serta salah sasaran dan inefisiensi dalam pengelolaan perbatasan, diharapkan dapat diperbaiki. Ruang lingkup tugas utama BNPP adalah mengelola Batas Wilayah Negara dan meningkatkan kesejahteraan masyarakat di kawasan perbatasan yang merupakan kristalisasi dari amanat UndangUndang Nomor 43 Tahun 2008 pasal 15 dan Peraturan Presiden Nomor 12 Tahun 2010 pasal 3, sebagai berikut: menetapkan kebijakan program pembangunan perbatasan; menetapkan rencana kebutuhan anggaran; mengkoordinasikan pelaksanaan; dan melaksanakan evaluasi dan pengawasan terhadap pengelolaan Batas Wilayah Negara dan Kawasan Perbatasan. ${ }^{17}$

\subsubsection{Politik Hukum Adat di Daerah Setempat}

Hukum adat tidak pernah menjadi hukum yang statis, walaupun masyarakatnya menganut dan menghayati adat mereka seperti yang telah ditetapkan oleh nenek moyang mereka untuk sekali dan selamanya tidak boleh melakukan penyimpangan. Hukum adat menjadi hukum yang bergerak terus untuk keadaan-keadaan yang dinamis. Masyarakat memahami struktur yang terjadi di daerahnya.

Setiap masyarakat memiliki struktur dan substansi hukum sendiri. Yang menentukan apakah substansi dan struktur hukum tersebut ditaati atau sebaliknya juga dilanggar adalah sikap dan perilaku sosial masyarakatnya. Dan, karena itu untuk memahami apakah hukum itu menjadi efektif atau tidak, sangat tergantung pada kebiasaan-kebiasaan (customs), kultur (culture), tradisi-tradisi (traditions), dan normanorma informal (informal norms) yang diciptakan dan dioperasionalkan dalam masyarakat yang bersangkutan.

Hukum adat sesungguhnya adalah sistem hukum rakyat (folk law) khas Indonesia sebagai pengejawantahan dari the living law yang tumbuh dan berkembang berdampingan (co-existance) dengan sistem hukum lainnya yang hidup dalam negara Indonesia. Walaupun disadari hukum negara cenderung mendominasi dan pada keadaan tertentu terjadi juga hukum negara menggusur, mengabaikan, atau

17 Tentang BNPP. http://bnpp.go.id/index.php/profil/tentang-bnpp/profil-bnpp .[Diakses pada tanggal 7 Juni 2017]. 
memarjinalisasi eksistensi hak-hak masyarakat lokal dan sistem hukum rakyat (adat) pada tatanan implementasi dan penegakan hukum negara. ${ }^{18}$

Dalam perspektif masyarakat hukum adat, masyarakat perbatasan secara geneologis dan teritorial, suku-suku di daerah perbatasan Papua dan Papua Nugini masih merupakan satu keturunan. Hubungan kekeluargaan yang tercipta di antara kedua masyarakat di daerah perbatasan ini sangat kuat sehingga memunculkan perspektif di dalam kehidupan bermasyarakat tentang perbatasan pada tingkat berbeda dengan perspektif politik yang dikonstruksikan oleh negara, di mana terdapat suatu adat istiadat/kebiasaan yang dipertahankan secara turun temurun dalam lintas generasi. Adat istiadat adalah sistem norma yang tumbuh, berkembang dan dijunjung tinggi oleh masyarakat penganutnya. Adat yang sudah melembaga dan berlaku turun temurun disebut tradisi atau kebiasaan. Kebiasaan, dalam pengertian yang paling sederhana adalah sesuatu yang telah dilakukan sejak lama dan menjadi bagian dari kehidupan suatu kelompok masyarakat, di mana kebiasaan ini dapat berbentuk tertulis maupun tidak tertulis. Kebiasaan-kebiasaan ini sangat mudah untuk punah atau hilang kalau tidak dilestarikan.

Tatanan masyarakat hukum adat di daerah perbatasan negara ini lebih tunduk terhadap hukum adatnya yang diterapkan secara turun menurun setiap generasi dalam memutuskan suatu permasalahan hukum. Perubahan politik hukum nasional tidak mampu menghilangkan solidaritas sosial dari hubungan masyarakat hukum adat yang dipisahkan oleh garis batas negara. Warga masyarakat hukum adat memiliki kebiasaan dan hukum adat yang berlaku ke dalam persekutuannya. Yang melanggar adat atau kebiasaan, pada umumnya akan dikenakan sanksi. Sanksi tersebut misalnya berupa pengucilan atau pengusiran dari lingkungan masyarakat di mana adat istiadat tersebut berlaku. Meskipun sanksi tersebut tidak tertulis tapi berfungsi efektif. Hal ini disebabkan karena adat-istiadat dihormati oleh warga masyarakat.

Di Indonesia, adat istiadat merupakan pelengkap hukum tertulis. Budaya adalah suatu cara hidup yang berkembang dan dimiliki bersama oleh sebuah kelompok orang dan diwariskan dari generasi ke generasi. Budaya terbentuk dari banyak unsur yang rumit, termasuk sistem agama dan politik, adat istiadat, bahasa, perkakas, pakaian, bangunan, dan karya seni.

Poltik hukum adat di daerah setempat sangat ditentukan oleh kebijakan yang diambil oleh persekutuan masyarakat hukum adat di wilayah adatnya. Kebijakan atau aturan yang diterapkan secara turun-temurun ini dilestarikan dan dijalankan serta aplikasikan di dalam kehidupan sehari-hari dengan baik oleh masyarakat hukum adat. Kebijakan adat bersifat mutlak dan tidak dapat diganggu gugat oleh persekutuan masyarakat hukum adat dan merupakan suatu peraturan yang harus dipenuhi dan ditaati selama pelaksanaan hukumnya. Masyarakat hukum adat dengan senang hati tunduk dan patuh terhadap putusan-putusan hukum yang ada dan ditetapkan oleh kepala adat dari persekutuan masyarakat hukum adatnya.

\subsection{Kedudukan Peraturan Perundang-undangan dan Politik Hukum Adat di Daerah Perbatasan}

Penegasan pancasila sebagai sumber tertib hukum inilah sangat besar artinya bagi hukum adat, karena hukum adat justru berurat berakar kepada kebudayaan rakyat, sehingga dapat

18 Eksistensi Hukum Masa Depan. http://www.boyyendratamin.com/2011/12/eksistensi-hukum-adat-dimasadepan.html . [Diakses pada tanggal 20 Mei 2017]. 
menjelmakan perasaan hukum yang nyata dan hidup di kalangan rakyat dan dengan demikian mencerminkan kepribadian bangsa dan masyarakat Indonesia. As a philosofische grondslag, Pancasila essentially as a source of legal order in Indonesia. In its position, Pancasila as source of elaboration in the process of law drafting in Indonesia. Pancasila that it contains religious values, the value of moral law, the value of natural law, and religious value as a legal source material for the positive law of Indonesia. ${ }^{19}$

Dengan penegasan pancasila sebagai sumber tertib hukum dalam pembukaannya ini, maka UUD 1945 pada hakikatnya menempatkan hukum adat pada posisi yang baru dalam tata perundang-undangan negara Indonesia. ${ }^{20}$ Secara tersirat, sebenarnya hukum adat dapat ditemukan dalam pasal II Aturan peralihan perundang-undangan yang masih menetapkan bahwa segala bangsa dan negara serta peraturan yang masih langsung berlaku selama belum diadakan yang baru. ${ }^{21}$ Setelah amandemen UUD NRI 1945 Pasal II aturan peralihan dialihkan menjadi Pasal I.

UUD NRI 1945 tidak menetapkan dengan tegas ketentuan khusus bagi hukum adat di dalamnya. Akan tetapi, secara tersirat hukum adat dinyatakan di dalamnya yaitu pada pembukaan dan penjelasan UUD NRI 1945. Karena hukum adat merupakan satu-satunya hukum yang berkembang di atas kerangka dasar pandangan hidup rakyat dan bangsa Indonesia, maka hukum adat selanjutnya merupakan sumber yang paling utama dalam pembinaan tata hukum nasional Negara Republik Indonesia.

Pengakuan terhadap hukum adat mengacu kepada undang-undang dasar 1945 di mana hukum adat diakui di dalam suatu sistem hukum di Indonesia. Keberadaan hukum adat dapat dikatakan memiliki kedudukan yang hampir sama dengan hukum nasional yang lebih tinggi dari UUD NRI 1945. Keberadaan hukum adat yang tidak terkodifikasikan, tidak terlihat, dan telah ada sebelum Negara Indonesia berdiri merupakan bukti bahwa hukum adat lebih berkuasa dari pada hukum nasional. Hukum adat merupakan nilai-nilai yang hidup dan berkembang di dalam masyarakat suatu daerah. Walaupun sebagian besar hukum adat tidak tertulis, tetapi ia mempunyai daya ikat yang kuat dalam masyarakat. Hukum adat yang hidup dalam masyarakat ini khususnya bagi masyarakat hukum adat Papua daerah perbatasan yang masih kental budaya aslinya akan sangat terasa. Penerapan hukum adat dalam kehidupan sehari-hari juga sering diterapkan oleh masyarakat hukum adat Papua.

Hukum bukanlah sesuatu yang terjadi secara alamiah, melainkan merupakan hasil resultante dari beraneka ragamnya proses internalisasi, intrusi dan negosiasi berbagai kepentingan di antara faksi-faksi dan aktor-aktor di dalam masyarakat. ${ }^{22}$ Jika melihat cita hukum menurut Gustav Radbruch, cita hukum dikalsifikasikan dalam 3 (tiga) prinsip umum yaitu: Purposivines (Kemanfaatan/Zweckmassigkeit), Justice (keadilan/Gerechtigheit), dan legal certainty (Kepastian hukum/rechtssicherheit). Idealnya ketiga unsur tersebut haruslah terdapat dalam hukum. Kendati demikian, untuk membuat hukum yang benar-benar proporsional, sesungguhnya sangat sulit karena cita hukum yang satu dengan yang lain pada dasarnya memiliki nilai-nilai yang saling bertentangan. ${ }^{23}$

19 Inggit AR, Andi Bau; dkk. (2017). Local Regulation Review in Realizes Legal Order of the Local Governance. Journal of Law, Policy and Globalization, ISSN 2224-3240 (Paper) ISSN 2224-3259 (Online), 59 (1). hlm. 214-219.

20 Wignjodipoegoro R. Soerojo. (1982). Kedudukan serta Perkembangan Hukum Adat setelah Kemerdekaan. Jakarta: Gunung Agung, hlm. 14-15.

$21 \quad$ Ibid. hlm. 17.

22 Zainal Arifin Mochtar. (2015). Antinomi dalam Peraturan Perundang-undangan di Indonesia. Hasanuddin Law Review, 1 (3), 316-336. hlm. 321. doi:http://dx.doi.org/10.20956/halrev.v1n1.212

23 Ibid. Lihat juga Torben Spaak. (2000). Meta-Ethic and Legal Theory: The Case of Gustav Radbruch. Journal Law and Philosophy, 28 (30), 261-290, dan Heather Leadwoods. (2000). Gustav Radbruch: An Extraordinary Legal Philosopher. Journal of Law an Policy. 
Walaupun hukum merupakan sistem yang teratur dan memiliki mekanisme mengatasi inkonsistensi, aspek ketidakteraturan hukum itu tetaplah ada. Ketidakteraturan dapat terjadi pada sikap tindak yang tidak sesuai dengan hukum atau mereka merasa bertindak menurut hak dan kewajiban menurut persepsinya masing-masing. ${ }^{24}$ Begitu juga dengan keberadaan masyarakat hukum adat di daerah perbatasan. Walaupun adanya pengaturan hukum Indonesia yang terikat dengan daerah kedaulatannya, tetapi keberadaan sistem hukum lainnya yang berada di daerah perbatasan tidak dapat dihindari. Ini terlihat dengan penerapan hukum PNG yang berada di daerah yurisdiksi NKRI. Inkonsistensi hukum nasional juga terlihat dari keberadaan hukum adat yang mempengaruhi sistem hukum di daerah perbatasan. Keberadaan hukum adat bisa mengalahkan keberadaan hukum nasional yang ada sehingga seharusnya adanya pembagian atau pemisahan dalam stelsel-stelsel hukum yang ada di daerah perbatasan.

Hukum sebagai aturan (peraturan perundang-undangan) secara operasional tidak dapat lepas dari sumber-sumber ilmu pengetahuan dan filsafat yang melandasi pembentukannya, sehingga manakala aturan tidak dapat memberikan kepastian dan keadilan, asas, teori dan filsafat menjadi hal yang penting dalam rangka pembaharuan dan harmonisasi untuk memberikan pemaknaan secara ilmiah terhadap suatu permasalahan yang ditimbulkan sejak proses pembentukan hingga pelaksanaan suatu undang-undang. ${ }^{25}$

Analisis terhadap persoalan dikotomi yang belum dirasa adil menempatkan teori social dominance $e^{26}$ sebagai rujukan dalam memetakan persoalan hukum adat dan peraturan hukum nasional serta aturan hukum PNG. Indonesia mencoba untuk membuat suatu peraturan yang berpusat pada politik hukum pemerintahan untuk menjaga dan melindungi keutuhan dan kedaulatannya tanpa melihat akan keberadaan hukum yang hidup di dalam suatu masyarakat. Hal ini terlihat dari banyaknya penerapan hukum dalam bentuk perundang-undangan yang bersifat sektoral dan menguntungkan bagi pemerintah dalam upaya menjaga keutuhan kedaulatan negara. Prinsip ini tidak salah melihat bahwa Negara Indonesia merupakan negara hukum dan memiliki kedaulatan serta yurisdiksi yang sah di dunia internasional dan nasional. Akan tetapi, tidak bisa dipungkiri bahwa keberadaan masyarakat hukum adat juga berada di daerah teritorial Negara Indonesia. Negara tetangga PNG dan keberadaan mereka menjelaskan bahwa pada kenyataannya perbatasan negara ini harus lebih diperhatikan karena adanya dualisme kepemilikan hak ulayat di suatu daerah perbatasan yang dimiliki oleh suatu kelompok masyarakat hukum adat yang berbeda kewarganegaraan.

Dalam konteks tersebut, apabila dibenturkan antara hukum nasional dan hukum adat serta hukum Negara PNG akan menjadi suatu permasalahan hukum yang tidak akan pernah selesai karena ketiga bentuk pengaturan hukum ini sangat berbeda untuk diterapkan secara bersamaan. Dalam kasus seperti ini sudah seharusnya melihat keberadaan living law yang berkembang di dalam suatu kehidupan masyarakat. Penerapan hukum yang sesuai akan memperoleh hasil yang tepat guna.

Kedudukan dari perundang-undangan di Indonesia bersifat mutlak dan harus ditaati dalam proses hukum jika melihat dari yurisdiksi Negara Kesatuan Republik Indonesia. Jika

24 Syarifuddin, Amir dan Indah Febriani. (2015). Sistem Hukum dan Teori Hukum Chaos. Hasanuddin Law Review. 1 (2), 296-306. hlm. 300. doi:http://dx.doi.org/10.20956/halrev.v1n1.212

25 Priyanta, Maret. (2015). Pembaharuan dan Harmonisasi Peraturan Perundang-undangan Bidang Lingkungan dan Penataan Ruang Menuju Pembangunan Berkelanjutan. Hasanuddin Law Review. 1 (3), 337-349. hlm. 348. doi:http://dx.doi.org/10.20956/halrev.v1n1.212

26 Sidanius memaparkan teori dominasi sosial, dimana kelompok cenderung untuk mendiskriminasi orang berdasarkan ideologi sosial yang ada dalam status kelompoknya, di mana kelompok yang lebih kuat cenderung bertingkah untuk kepentingan mereka sendiri dan berupaya untuk mendiskriminasi kelompok lemah. Lihat: Sidanius, dkk. (2004). Social Dominance Theory: Its Agenda and Method. Journal Political Psychology, Vol. 25, No. 6. 
melihat dari persekutuan hukum adatnya berarti hukum adat yang berlaku. Akan tetapi, keberadaan masyarakat hukum adat yang berkewarganegaraan PNG yang tinggal dan bermukim di Indonesia sudah seharunya menggunakan hukum Indonesia bukan menggunakan hukum yang pernah di bawah olehnya dari PNG.

Realitas kehidupan masyarakat hukum adat di daerah perbatasan tetap berada di dalam lingkungan adat dan adat istiadatnya, meskipun selama ini ada gesekan-gesekan dari pengaruh global. Mereka tetap memelihara tatanan kehidupan bermasyarakat dengan ikatan kebersamaan, yang berprinsip kepada ketenangan, kerukunan dan kedamaian dalam kehidupan sosial antar masyarakat hukum adatnya. Keberadaan masyarakat hukum adat tidak terusik dengan persoalan hukum nasional karena pada hakikatnya kedudukan hukum adat di daerah perbatasan Papua adalah hukum tertinggi di dalam persekutuan masyarakat hukum adatnya. Hal ini membuktikan bahwa kedudukan hukum adat di Indonesia merupakan hukum bangsa asli Indonesia yang selalu dipertahankan oleh masyarakat yang bersangkutan. Andaikata hukum nasional menghapus hukum adat, maka hukum nasional akan kehilangan sumber dayanya dan hukum adat tidak akan pernah mati, karena hukum adat adalah pangkal dari segala sumber hukum Indonesia, yang menjelma dalam pancasila.

Undang-undang Dasar (UUD) dan hukum adat berasal dari rechtsidee/cita hukum sehingga UUD dan hukum adat mengikuti dan tunduk pada cita hukum. Cita hukum sebagai batu penguji dari segala macam norma hukum yang ada, karena letaknya sebagai jiwa atau dasar dari hukum dasar. Menurut Von Savigny bahwa hukum berasal dari jiwa bangsa maka hukum dasar berangkat dari hukum yang hidup dan berkembang sesuai dengan nilai-nilai kehidupan dalam masyarakat. Berdasarkan penjelasan di atas kedudukan hukum adat dan UUD 1945 adalah berbeda di mana rechtidee UUD adalah hukum adat Indonesia karena di dalam UUD NRI 1945 memuat jiwa bangsa dan nilai-nilai hukum yang hidup dalam masyarakat yang berkembang. Sedangkan kedudukan hukum adat adalah cita hukum dari hukum dasar yang memiliki kedudukan yang paling kuat dalam tata hukum Indonesia di mana hukum adat menjiwai seluruh hukum yang ada di dalam tata hukum Indonesia yang dijadikan dasar uji dari hukum-hukum yang diciptakan.

Dengan demikian kedudukan pengaturan hukum adat yang berlaku di daerah perbatasan memiliki kedudukan hukum yang paling kuat dalam tata hukum di daerah perbatasan di mana hukum adat merupakan cita dasar dan hukum dasar di antara persekutuan masyarakat hukum adat begitu juga dengan poltik kebijakan pemerintah daerah yang ada merupakan penjiwaan dari hukum adat yang berkembang di masyarakat.

\section{Conclusion}

Dikotomi pengaturan sistem hukum yang ada di daerah perbatasan merupakan bentuk pengaturan hukum yang plural dan beraneka ragam. Akan tetapi pada hakikatnya dikotomi hukum yang ada di daerah perbatasan harus dibedakan dalam proses penerapannya, di mana peraturan hukum nasional, hukum adat dan hukum PNG merupakan sesuatu yang berbeda dan harus dipisahkan. Hukum Indonesia berlaku terhadap warga Negara Indonesia, hukum adat berlaku pada persekutuan masyarakat hukum adat dan hukum PNG berlaku terhadap masyarakat hukum adat yang berasal dari PNG. Akan tetapi, sinergitas terhadap penerapan hukum di antara persekutuan masyarakat hukum adat yang hidup di daerah perbatasan bisa menggunakan hukum adat yang hanya berlaku di antara persekutuan masyarakat adatnya.

Kedudukan hukum nasional dan politik hukum adat yang ada di daerah perbatasan pada hakikatnya adalah sama, di mana hukum nasional harus berlaku terhadap seluruh warga masyarakatnya tidak terkecuali dengan masyarakat hukum adat yang ada di daerah yurisdiksi Negara Indonesia. Begitu juga dengan masyarakat hukum adat PNG harus tunduk terhadap 
hukum yang berlaku yaitu hukum Indonesia apabila mereka tinggal dan hidup di daerah yurisdiksi Negara Indonesia. Walaupun kedudukan hukum nasional Indonesia begitu tinggi, tetapi keberadaan hukum adat juga tidak dapat dikesampingkan karena di dalam persekutuan masyarakat hukum adatnya hukum adat memiliki kedudukan yang tinggi karena merupakan hukum yang asli dari suatu suku bangsa yang ada di daerah perbatasan.

\section{Ucapan Terima Kasih}

Terimakasih saya ucapkan kepada tim editorial Amsir Law Journal atas publikasi tulisan kami di volume 1, bulan Oktober 2019.

\section{Referensi}

Buku:

Arinanto, Satya dan Ninuk Triyanti. (2009). Memahami Hukum: dari Konstruksi sampai Implementasi. Jakarta: Rajawali Press.

Koentjaraningrat. (1990). Pengantar Ilmu Antropologi. Jakarta: PT. Rineka Cipta.

Mulyana, Dedi dan Jalaluddin Rakhmat. (2005). Komunikasi Antarbudaya; Panduan Berkomunikasi dengan Orang-orang Berbeda Budaya. Bandung: Remaja Rosdakarya.

Partanto, Pius A. dan M. Dahlan Al-Barry. (1995). Kamus Ilmiah Populer. Surabaya: Arkola.

Rudito, Bambang dan Melia Famiola. (2013). Social Mapping- Metode Pemetaan Sosial: Teknik Memahami Suatu Masyarakat atau Komuniti (edisi revisi). Bandung: Rekayasa Sains.

Tim Penyusun Kamus Pusat Bahasa. (2001). Kamus Besar Bahasa Indonesia. Jakarta: Balai Pustaka.

Wignjodipoegoro R. Soerojo. (1982). Kedudukan serta Perkembangan Hukum Adat setelah Kemerdekaan. Jakarta: Gunung Agung.

Artikel Jurnal:

Bakri, Muhammad. (2008). Unifikasi dalam Pluralisme Hukum Tanah di Indonesia (Rekonstruksi Konsep Unifikasi dalam UUPA. Jumal Kertha Patrika. 33 (1), 1-5.

Inggit AR, Andi Bau; dkk. (2017). Local Regulation Review in Realizes Legal Order of the Local Governance. Journal of Law, Policy and Globalization, ISSN 2224-3240 (Paper) ISSN 2224-3259 (Online), 59 (1).

Irwansyah. (2017). Research-Based Environmental Law: The Debate Between Ecology Versus Development. Sriwijaya Law Review. 1 (1), 44-66.

Likadja, Jeffry Alexander Ch. (2015). Memaknai "Hukum Negara (Law Throught State)" dalam Bingkai "Negara Hukum (Rechtstaat)". Hasanuddin Law Review. 1 (1), 75-86. doi:http://dx.doi.org/10.20956/halrev.v1n1.212

Marzuki, H.M. Laica. (2006). Kekuatan Mengikat Putusan Mahkamah Konstitusi terhadap Undang-undang, Jurnal Legislasi. 3 (1). 
Priyanta, Maret. (2015). Pembaharuan dan Harmonisasi Peraturan Perundang-undangan Bidang Lingkungan dan Penataan Ruang Menuju Pembangunan Berkelanjutan. Hasanuddin Law Review. 1 (3), 337-349. doi:http://dx.doi.org/10.20956/halrev.v1n1.212

Sidanius, dkk. (2004). Social Dominance Theory: Its Agenda and Method. Journal Political Psychology, Vol. 25.

Syarifuddin, Amir dan Indah Febriani. (2015). Sistem Hukum dan Teori Hukum Chaos. Hasanuddin Law Review. 1 (2), 296-306. doi:http:/ /dx.doi.org/10.20956/halrev.v1n1.212

Zainal Arifin Mochtar. (2015). Antinomi dalam Peraturan Perundang-undangan di Indonesia. Hasanuddin Law Review, 1 (3), 316-336. doi:http://dx.doi.org/10.20956/halrev.v1n1.212

World Wide Web:

http://www.boyyendratamin.com/2011/12/eksistensi-hukum-adat-dimasa-depan.html . [Diakses pada tanggal 20 Mei 2017].

http://bnpp.go.id/index.php/profil/tentang-bnpp/profil-bnpp .[Diakses pada tanggal 7 Juni 2017].

https://elshinta.com/news/86604/2016/11/08/sejumlah-warga-papua-nugini-pindahke-indonesia, lihat juga http://beritamerauke.blogspot.co.id/2009/02/57-warga-pngingin-kembali-ke-merauke.html

\section{Conflict of Interest Statement:}

The author declares that the research was conducted in the absence of any commercial or financial relationships that could be construed as a potential conflict of interest. 